\title{
The role of vitamin $D$ in the human body with a special emphasis on dental issues: Literature review
}

\section{Rola witaminy D w organizmie ze szczególnym uwzględnieniem jej znaczenia w patologiach jamy ustnej - przegląd piśmiennictwa}

\author{
Maciej Krawiec ${ }^{A-D}$, Marzena Dominiak ${ }^{A, E, F}$ \\ Department of Oral Surgery, Faculty of Dentistry, Wroclaw Medical University, Poland \\ A - research concept and design; $B$ - collection and/or assembly of data; $C$ - data analysis and interpretation; \\ $D$ - writing the article; $E$ - critical revision of the article; $F$ - final approval of the article
}

\section{Address for correspondence \\ Maciej Krawiec}

E-mail: maciejkrawiec@ptss.pl

\section{Funding sources}

None declared

Conflict of interest

None declared

Received on April 30, 2018

Reviewed on June 4, 2018

Accepted on October 18, 2018

Published online on December 28, 2018

Krawiec M, Dominiak M. The role of vitamin D in the human

body with a special emphasis on dental issues: Literature review].

Dent Med Probl. 2018;55(4):419-424.

doi:10.17219/dmp/99051

D0I

10.17219/dmp/99051

Copyright

๑) 2018 by Wroclaw Medical University

and Polish Dental Society

This is an article distributed under the terms of the

Creative Commons Attribution Non-Commercial License

(http://creativecommons.org/licenses/by-nc-nd/4.0/)

\begin{abstract}
The aim of the study was to review the current literature on the role of vitamin $D$ in dentistry. The term vitamin $D$ is defined as a group of compounds which are cholesterol derivatives with a similar chemical structure. It is produced in the human body and passes through many stages of synthesis. Vitamin D affects our body through the immune, muscular, nervous, and cardiovascular systems. It is also relevant in dentistry and in the carbohydrate metabolism. Nowadays, vitamin D deficiency levels are high in both the Polish and the world population as a whole. This is due to many factors: latitude, diseases and lifestyle. The data shows that over $90 \%$ of people of color (black, Latino, Asian, etc.) and nearly $3 / 4$ of whites living in the United States suffer from a shortage of 25-hydroxycholecalciferol $(25(\mathrm{OH})$ vitamin D). Meanwhile, studies performed in Poland report that a concentration of vitamin D $<20 \mathrm{ng} / \mathrm{mL}(50 \mathrm{nmol} / \mathrm{mL})$ occurs in $70 \%$ of the population. Preliminary reports suggest that vitamin $\mathrm{D}$, through the maintenance of normal bone metabolism, as well as its antibacterial and anti-inflammatory activity, modulates periodontal disease. A normal level of vitamin $\mathrm{D}$ is important in the treatment of periodontitis. More and more studies are focusing on the problem of vitamin $D$ deficiency and its role in the human body. It is very important to maintain normal levels of vitamin D in the blood and supplement it in the case of shortfalls.
\end{abstract}

Key words: periodontitis, vitamin D, vitamin D deficiency, calcitriol

Słowa kluczowe: zapalenie przyzębia, witamina D, niedobór witaminy D, kalcytriol 


\section{Introduction}

The term vitamin D refers to a group of chemical compounds that are cholesterol derivatives. Their similar chemical construction includes rings $\mathrm{A}, \mathrm{B}, \mathrm{C}$, and $\mathrm{D}$, and a side chain. Due to the $B$ ring opening, vitamin D is classified as belonging to the secosteroid compound group. Vitamin D occurs in 2 basic forms: cholecalciferol (vitamin $D_{3}$ ) and ergocalciferol (vitamin $D_{2}$ ). They differ in terms of their side chain structure and their occurrence - cholecalciferol is present in animal organisms, while ergocalciferol is found in plants and fungi.

The PubMed database of the U.S. National Library of Medicine and the Thomson Reuters Web of Knowledge were used as electronic databases to perform a systematic search for relevant articles published in the dental literature between 1969 and 2015. The combination of key words (i.e., Medical Subject Headings - MeSH) and free text terms included: [periodontitis OR periodontal disease] AND [vitamin D OR calcitriol] AND [vitamin D deficiency].

The electronic search was complemented by a hand search of the following journals: "Journal of Clinical and Diagnostic Research" and "Journal of Periodontology".

\section{Vitamin D metabolism}

The synthesis of biologically active molecules in the human body involves a number of stages. The reaction precursor is a cholesterol derivative - 7-dehydrocholesterol. It is present in the plasma membrane of keratinocytes, in the basal and spinous layer (called the Malpighian layer; at a volume of $0.4 \mathrm{mg} / \mathrm{cm}^{2}$ ) and in dermis fibroblasts, where under UV radiation (wavelengths of 290-315 nm), in a photochemical reaction, it is transformed over the course of $30 \mathrm{~min}$ into lumisterol or tachysterol.

Next, at a high temperature (a skin temperature of $25^{\circ} \mathrm{C}$ ) and with the participation of a reductase enzyme, isomerization to cholecalciferol (calciol) begins. This is a stable compound, which is released into the extracellular matrix and then into the blood, where it binds to a specific globulin, which in turn binds vitamin D (vitamin D binding protein - DBP) and is transported to the liver. The $1^{\text {st }}$ hydroxylation process takes place in the presence of vitamin D 25-hydroxylase, which is dependent on P-450 cytochrome (CYP27A1). This leads to the creation of 25-hydroxycholecalciferol $(25(\mathrm{OH})$ vitamin $\mathrm{D}$, calcidiol). The biological activity of this compound is low and its surplus is stored in adipocytes.

The next stage that takes place in renal proximal tubules is $1 \alpha$-hydroxylation of the calcidiol A ring, involving 1 $\alpha$-hydroxylase (CYP27B1). During this reaction, 1,25-dihydroxy-cholecalciferol $\left(1,25(\mathrm{OH})_{2}\right.$ D3, calcitriol) is formed. It is described as a vitamin hormone, the activity of which is 1,000 times higher as compared to calcidiol, but its half-life is shorter, i.e., 4-6 h. Calcitriol regulates numerous processes in the body, e.g., renal excretion of calcium ( $\mathrm{Ca}$ ) and phosphate with the urine, and increases osteolytic activity of parathyroid hormone (parathormone, PTH). Moreover, it lowers the immunity of the bone tissue to PTH activity, sensitizes parathyroid cells to calcemia transitions, increases the number of $\mathrm{Ca}$ ion receptors, simplifies the flow of ions to parathyroid cells and therefore reduces the secretion of PTH, and takes part in $\mathrm{Ca}$ absorption from the digestive tract. Calcitriol plays an essential role in the mineralization of bones, regulates the immunological processes, has an impact on cell proliferation and differentiation, and also may increase myopathy and cardiomyopathy. ${ }^{1}$ This stage in the synthesis process is activated by the accumulation of $1,25(\mathrm{OH})_{2} \mathrm{D} 3$ metabolite, hypocalcemia, hypophosphatemia, and an elevated concentration of PTH. Tyrosine, estrogens, androgens, insulin, prolactin, cortisol, and somatotropin also exert a positive impact on hydroxylation. ${ }^{2}$

What is essential is that the $1 \alpha$-hydroxylation process also occurs in other human cells, such as macrophages, keratinocytes, placenta, parathyroid and prostate cells, osteoblasts, immune system cells, pancreatic islets, smooth muscle tissue cells, and tumor cells. Locally synthesized vitamin $\mathrm{D}$ impacts physiological processes at synthesis points $^{3-5}$ by auto- and paracrine regulation. Vitamin D is also delivered to the body through a proper diet, although it only accounts for approx. $10 \%$ of the total concentration. Products rich in cholecalciferol include fish and cod-liver oil. Milk, eggs and cheese also contain cholecalciferol, but in lower amounts. Legume plants are rich in ergocalciferol.

\section{The vitamin D receptor}

Vitamin D affects the human body and its particular systems by binding with a specific calcitriol receptor called the vitamin D receptor (VDR). It is present in over 30 tissues and organs, including the bones, kidneys, intestine, heart, brain, skin, pancreas, blood vessels, hypophysis, adrenal glands, and striated and smooth muscle tissue, as well as in T and B lymphocytes, neutrophils and macrophages. This suggests that the functioning of vitamin $D$ is pleiotropic (heliotropic) in character.

The vitamin D receptor belongs to the steroid hormone receptor superfamily. It is a specific nuclear receptor. Its molecular mass equals approx. $55 \mathrm{kDa}$, it consists of 427 amino acid residues and is encoded by the VDR gene. The gene which encodes the vitamin $D$ receptor protein is located in the $2^{\text {nd }}$ arm of chromosome 12 . It consists of 9 exons, which are transcriptional DNA sequences, and of intertwined mRNA particles, which create transcriptional RNA. This gene is highly volatile due to mutations in the non-coded region.

Several polymorphisms of the VDR gene are known. The most common are single nucleotide polymorphisms 
(SNPs) - FokI (C/T), BsmI (A/G), ApaI (A/C), TaqI (T/C), and $\mathrm{Cdx} 2(\mathrm{~A} / \mathrm{G})$. Their names come from the restriction site that was originally used to identify them. FokI (rs2228570, C/T) polymorphism is located in the $2^{\text {nd }}$ start codon (ATG) in exon 2. When the C (mutant) allele is present, an alternative start site is used, leading to the expression of a shorter VDR protein (424 aa), which demonstrates a greater transcriptional activity as a consequence of enhanced binding to transcription factor II B. The $\mathrm{T}$ (wild-type) allele leads to the expression of a longer VDR protein (427 aa). ${ }^{6}$ BsmI (rs1544410), ApaI (rs7975232) and TaqI (rs731236) polymorphisms are located in the 3' untranslated region (UTR), and are all involved in regulating the stability of VDR mRNA. ${ }^{7,8}$

The calcitriol receptor comprises 2 important fragments. The larger fragment (ligand-binding domain; the activation function for regulating gene transcription through calcitriol) is responsible for binding with the active form of vitamin D, and the smaller fragment (DNAbinding domain; dimerization) is responsible for binding with the regulatory DNA sequences of protein coding genes, whose expression is modulated by vitamin D (i.e., osteocalcin, osteopontin, collagen, alkaline phosphatase, hydroxycholecalciferol, parathyroid hormone). ${ }^{1,9}$ There are over 50 genes involved in $\mathrm{Ca} / \mathrm{P}$ homeostasis. They are responsible for cell proliferation and differentiation, and immune response.

The ligand-binding domain with calcitriol is characterized by a low yield but a high affinity. It is composed of 80 amino acids, where 20 combine to build 2 tin fingers, with 3 amino acids that are crucial at the base. Here, after calcitriol binding, serine residue phosphorylation begins in positions 51,119 and 125 . Due to this process, it is possible to recognize the characteristic sequence in the promoter region of the target gene - vitamin D-responsive element (VDRE). The modification of the binding domain of the ligand may result in a lack of or poor responses to vitamin D. ${ }^{10,11}$

The dimerization domain is located near the ligandbinding domain. It consists of a sequence of 7 hydrophobic amino acids, repeated 9 times. The binding of calcitriol induces a conformational change in the dimerization domain, which enables the binding to the retinoic acid receptor-retinoid $\mathrm{X}$ receptor (RXR) so as to form a heterodimer, and then the specific binding of the heterodimer to the regulatory sequences of DNA.1,2,12,13

\section{Vitamin D: Deficiency, determination and supplementation}

Epidemiological studies show that vitamin D deficiency is a very common occurrence, not only in the Polish population, but also globally. ${ }^{14}$ This deficiency is determined by a concentration of $<30 \mathrm{ng} / \mathrm{mL}$ (75 nmol/ $\mathrm{mL}$ ) in the blood serum. Adams and Hewison have pub- lished data which shows that over $90 \%$ of people of color (black, Latino and Asians) and nearly 3/4 of whites living in the United States suffer from a shortage of $25(\mathrm{OH})$ vitamin D. ${ }^{15,16}$ Meanwhile, studies performed in Poland report that a concentration of vitamin $\mathrm{D}<20 \mathrm{ng} / \mathrm{mL}$ (50 $\mathrm{nmol} / \mathrm{mL}$ ) occurs in $70 \%$ of the population. ${ }^{17,18}$

The main reasons for vitamin D deficiency are as follows: latitude (though also in countries with high insolation, such as India, vitamin D deficiency is becoming a growing problem), usage of UVB filters, lifestyle, vocation, melanin deficiencies in the skin, aging, air pollution, inadequate dietary intake and supplements. ${ }^{19,20}$ An inadequate concentration of vitamin $\mathrm{D}$ is also accompanied by other diseases: cirrhosis of the liver, kidney dysfunctions, malabsorption, and obesity. It can also be a consequence of drug treatment (long-term intake of glucocorticoids, anti-epileptic drugs or ketoconazole).

Vitamin D concentration in the serum is determined using immunochemical methods, or a more accurate and sensitive technique of liquid chromatography-tandem mass spectrometry (LC-MS/MS). This method consists in isolating a single ion from a substance present in the sample by calculating the fraction mass-to-charge of ions. In tests determining vitamin $\mathrm{D}$ levels, liquid chromatography (LC) is used, which in the initial phase can precisely extract particles for further spectrometer analysis. 25-hydroxyvitamin D (25(OH)D), due to its stability in the serum and the fact that the speed of its synthesis is dependent on the supply of ingested vitamin $\mathrm{D}$ from diet, drugs or supplements, it is regarded as a marker and the best indicator of vitamin $\mathrm{D}$ concentration in the body. It is worth performing laboratory tests to measure both subunit 25(OH)D2 and 25(OH)D3. The sum of their total concentrations represents the total vitamin D concentration in the serum. ${ }^{21}$

Depending on the level of vitamin D deficiency and the age of the patient, various supplementation doses have been proposed. Table 1 shows the dosing regimen for adults aged $>18$ years according to the concentration of vitamin D. The recommended total dose of vitamin D in therapy can also be calculated using the Groningen formula $^{22}$ :

$$
\begin{gathered}
40 \times(75-\text { concentration of } 25(\mathrm{OH}) \mathrm{D}[\mathrm{nmol} / \mathrm{L}]) \times \\
\times \text { body weight }[\mathrm{kg}]
\end{gathered}
$$

where $1 \mathrm{ng} / \mathrm{mL}=2.5 \mathrm{nmol} / \mathrm{mL}$.

It is essential that supplementation in the form of tablets is applied after a meal, due to better absorption and the presence of agents containing vitamin $\mathrm{K}_{2} \mathrm{MK}-7$, which affects bone metabolism through activating and enhancing matrix Gla-protein (MGP). The supply may be carried out using ergocalciferol (vitamin $\mathrm{D}_{2}$ ), cholecalciferol (vitamin $\left.\mathrm{D}_{3}\right)$ or calcifediol $(25(\mathrm{OH}) \mathrm{D} 3)$. The latter is used in the treatment of liver diseases, and complications arising 
Table 1. Dose of vitamin D in relation to its concentration in the blood

Concentration of $25(\mathrm{OH})$ vitamin $\mathrm{D}$ in the blood

Correct values

Correct values; obese people

Correct values; lack of effective synthesis in the skin

$<20 \mathrm{ng} / \mathrm{mL}$

20-30 ng/mL
Supplementation doses

800-2,000 IU/day in the September-April period; max dose for healthy people: 4,000 IU/day

1,600-4,000 IU/day throughout a year

800-2,000 IU/day throughout a year

$10,000 \mathrm{IU} /$ day or 50,000 IU/week with a control test after 3 months

8,000 IU/day with a control test after 3 months
25(OH) vitamin D - 25-hydroxycholecalciferol.

from glucocorticosteroid treatment and antiepileptic drugs. The administration of calcitriol and its derivatives has no effect on improving the performance of vitamin $\mathrm{D}_{3}$, defined as an increase in the concentration of $25(\mathrm{OH})$ D3 in the serum, and is treated as hormonal treatment.

\section{Vitamin D in medicine}

Due to the discovery of the presence of VDR in many tissues, it has been proven that the effects of its action are wide and regard many systems. Its influence, beyond the skeletal system, has been shown for example in the immune, muscle, neural, and circulatory systems, as well as in dermal diseases, rheumatic diseases, mental disorders, and in anticancer activities. Thanks to such multidirectional effects, vitamin $\mathrm{D}$ has become known as the vitamin of life.

\section{Vitamin D in dentistry}

Vitamin D plays an important role in the stomatognathic system, where its influence in preventing caries has been demonstrated. An analysis by Hujoel points to vitamin $\mathrm{D}$ as one of the promising factors preventing caries. ${ }^{23}$ The same study showed that vitamin D supplementation was correlated with a $47 \%$ lower risk of caries. This effect was achieved through better tooth development, changes in the amount or biochemical composition of saliva, modulated caries activity due to immunological factors, ${ }^{24-26}$ and stimulating the production of antimicrobial peptides, such as defensins and cathelicidin. ${ }^{27}$ It is also known that vitamin D can modulate Behçet's disease, aphthous stomatitis and Sjögren's syndrome. ${ }^{27}$ There are reports on the existence of a correlation between the level of vitamin D and the activity of various diseases, including acromegaly. ${ }^{28,29}$ Halupczok-Żyła et al. found vitamin $\mathrm{D}$ deficiency in all patients with the active form of acromegaly. ${ }^{29}$ There was also a statistically significant difference in the level of vitamin D between the control group and active acromegaly patients. ${ }^{29}$

Another study suggests that VDR FokI genotypes might affect the development of acromegaly and VDR polymorphisms, and may play a role in the course of acromegaly as a consequence of altering the hormonal status. ${ }^{30}$
Vitamin D is also capable of modifying the course of periodontal disease. There are 3 basic mechanisms responsible for this: the maintenance of normal bone metabolism, antibacterial activity and anti-inflammatory activity. The impact of vitamin D and its active metabolites on the skeletal system occurs through the regulation of the Ca metabolism. The level of $25(\mathrm{OH})$ vitamin $\mathrm{D}$ in the serum is positively correlated with the degree of bone mineralization, and negatively with the concentration of PTH.

Chronic vitamin D deficiency results in abnormal Ca absorption in the small intestine, which in turn reduces its blood concentration. In consequence, parathyroid glands increase the production of PTH (thereby developing tertiary hyperparathyroidism), which, by affecting the bone, increases the release of $\mathrm{Ca}$ into the blood to compensate for the deficiency in the serum.

This process is driven by the activation of osteoclasts, which results in the destruction of bone tissue, leading in turn to a reduction in bone calcification, rickets, osteomalacia, and osteoporosis. The role of vitamin D in the bone mineralization process can be proven by the fact that the condition of bone tissue deteriorates during the winter/spring, when the synthesis of vitamin D through the action of sunlight is considerably reduced. ${ }^{31}$

Vitamin D can reduce bone resorption by increasing intestinal absorption of $\mathrm{Ca}$ and its reabsorption in the distal renal tubules. However, it also accelerates the secretion of calcitonin and decreases parathyroid cell proliferation, which in turn inhibits the synthesis and activity of PTH. It also aids bone repair processes and bone matrix synthesis, reduces the perforation of trabeculae and increases the activity of bone growth factors.

The antibacterial activity of vitamin $\mathrm{D}$ is based primarily on the induction of secretion of beta-defensins and cathelicidin LL-37 (showing the chemotactic activity of neutrophils, monocytes and T lymphocytes), for example by human gingival epithelial cells (GEC), and thereby modulating the innate immune response. Another important issue is the fact that calcitriol affects the regulation of triggering receptor expressed on myeloid cells (TREM-1), which is a key amplifier initiating the immune responses of macrophages, which in turn leads to increased production of inflammatory response genes. This information suggests that vitamin D may be used to treat and prevent infectious diseases of the mouth. ${ }^{32}$ 
The final impact of vitamin $\mathrm{D}$ on the mouth consists in its anti-inflammatory activity. It has been shown to inhibit the release of cytokines, including interleukin $1 \beta$ (IL-1 $\beta$ ), interleukin 6 (IL-6), interleukin 12 (IL-12), and tumor necrosis factor (TNF), help decrease the number of $\mathrm{T}$ and $\mathrm{B}$ cells, and block the proinflammatory activity of type 1 and type 17 helper (Th1 and Th17) cells.

In light of all the reports mentioned above, researchers have begun to closely observe and study any possible correlation between the effects of vitamin $D$ and the course of periodontal diseases. ${ }^{33-36}$ Vitamin D has a multi-level role in maintaining periodontal health, namely, in reducing alveolar bone loss, gingival inflammation and/or attachment loss. Dietrich et al. used the Third National Health and Nutrition Examination Survey (NHANES III) to show that a lower level of vitamin D is associated with greater loss of attachment. ${ }^{36}$ Another interesting conclusion of this analysis was that people with high vitamin D levels showed $20 \%$ less bleeding on probing. It is worth noting that these results were independent of other factors, such as diabetes or smoking. Such effects are evidence of the anti-inflammatory activity of vitamin D. ${ }^{37}$

Studies conducted by Perayil et al. demonstrated the inhibiting effect of vitamin D and Ca supplementation on periodontitis. ${ }^{38}$ They observed a statistically significant decrease in gingival index (GI) and simplified oral hygiene index (OHI-S) among patients taking an additional $250 \mathrm{IU}$ of vitamin D and $500 \mathrm{mg}$ of $\mathrm{Ca}$, compared to those patients whose treatment consisted solely in scaling, root planing and curettage. Moreover, the bone density of respondents from the experimental group significantly increased. Hiremath et al. showed that vitamin D was a safe and effective anti-inflammatory agent when used in the treatment of gingivitis. ${ }^{39}$ This characteristic leads to a reduced risk of tooth loss. ${ }^{40}$

According to Mangano et al., the risk of early implant loss is more than 4 times higher in people with deficient vitamin $\mathrm{D}(<10 \mathrm{ng} / \mathrm{mL})$ than in patients with normal serum vitamin D levels. ${ }^{41}$

\section{Conclusions}

The above discussion points out the importance of maintaining normal levels of vitamin D in the blood. Scientists have again started to examine the effect of vitamin $D$ on many processes. They also highlight the fact that there is a general deficiency of vitamin D and the need for appropriate supplementation.

An analysis of the available publications clearly shows that more attention should be paid to the role of vitamin D deficiency in the etiology and treatment of periodontal diseases, as well as to vitamin D supplementation as an aid in treating periodontitis and gingivitis. In addition, it is worth focusing on possible vitamin D deficiency as a factor that increases the risk of bone implant loss.

\section{References}

1. August R, Gumprecht J, Karasek D, et al. Polymorphism A, B and T of the receptor gene for vitamin $D$ and bone density in diabetic patients with terminal renal failure treated with renal replacement therapy [in Polish]. Diabetol Doświad Klin. 2003;3:61-70.

2. Tuchendler $D$, Bolanowski $M$. Seasonality of changes in vitamin $D$ concentrations in the human body [in Polish]. Endokrynol Otył Zab Przem Mat. 2010;6:36-41.

3. Alpert PT, Shaikh U. The effects of vitamin D deficiency and insufficiency on the endocrine and paracrine systems. Biol Res Nurs. 2007;9:117-129.

4. DeLuca HF. Overview of general physiologic features and functions of vitamin D. Am J Clin Nutr. 2004;80:1689-1696.

5. Grygiel-Górniak B, Puszczewicz M. Vitamin D - a new look in medicine and rheumatology [in Polish]. Postepy Hig Med Dosw. 2014;68:359-368.

6. Kaleta B, Walicka M, Sawicka A, et al. Vitamin D receptor gene polymorphism in Polish patients with morbid obesity [in Polish]. Post Nauk Med. 2014;1:65-69.

7. Uitterlinden A, Fang Y, Van Meurs J, Pols H, Van Leeuwen J. Genetics and biology of vitamin D receptor polymorphisms. Gene. 2004;338:143-156.

8. Yang C, Li J, Li Y, et al. The vitamin D receptor gene Apal polymorphism is associated with increased risk of renal cell carcinoma in Chinese population. Sci Rep. 2016;6:25987.

9. Alegretto EA, Pike JW. Tripsin cleavage of chick 1.25-dihydroxyvita$\mathrm{min} D$ receptors. Generation of discrete polypeptides which retain hormone but are uncreative to DNA and monoclonal antibody. J Biol Chem. 1985;260:10139-10145.

10. Haussler MR, Norman A. Chromosomal receptor for a vitamin $D$ metabolite. Proc Natl Acad Sci USA. 1969;62:155-162.

11. Norman AW. Minireview: Vitamin D receptor: New assignments for an already busy receptor. Endocrinol. 2006;147:5542-5548.

12. Sprague SM, Popovtzer MM. Is beta2-microglobulin a mediator of bone disease? Kidney Int. 1995;47:1-7.

13. Freedman $L P$, Luisi $B F$, Korszun $Z R$. The function and structure of metal coordination sites within the glucocorticoid receptor DNA binding domain. Nature. 1988;334:543-546.

14. Olędzka R. Vitamin D in the light of recent studies [in Polish]. Bromat Chem Toksykol. 2013;46:121-131.

15. Adams JS, Hewison M. Update in vitamin D. J Clin Endocrinol Metab. 2010;95:471-478.

16. Holick MF. Ressurection of vitamin D deficiency and rickets. J Clin Invest. 2006;116:2062-2072.

17. Płudowski P, Karczmarewicz E, Chlebna-Sokół D, et al. Vitamin D supplementation in healthy population and risk groups of vitamin $D$ deficiency - practice guidelines for Central Europe 2013 [in Polish]. Stand Med Pediatr. 2013;10:573-578.

18. Karczmarewicz E, Czekuć- Kryśkiewicz E, Płudowski P. Effect of vitamin D status on pharmacological treatment efficiency. Impact on cost-effective management in medicine. Dermatoendocrinol. 2013;5:299-304.

19. Żukowska-Szczechowska E, Kiszka B. Vitamin D deficiency - diagnosis and management in order to reduce cardiovascular risk in patients with diabetes [in Polish]. Forum Zab Metabol. 2011;2:151-157.

20. Holick M. Vitamin D deficiency. N Engl J Med. 2007;357:266-281.

21. Płudowski $P$, Karczmarewicz E, Bayer $M$, et al. Practical guidelines for the supplementation of vitamin $D$ and the treatment of deficits in Central Europe - recommended vitamin D intakes in the general population and groups at risk of vitamin D deficiency. Endokrynol Pol. 2013;64:319-327.

22. van Groningen L, Opdenoordt S, van Sorge A, Telting D, Giesen A, de Boer $\mathrm{H}$. Cholecalciferol loading dose guideline for vitamin D-deficient adults. Eur J Endocrinol. 2010;162:805-811.

23. Hujoel P. Vitamin $D$ and dental caries in controlled clinical trials: Systematic review and meta-analysis. Nutr Rev. 2013;71:88-97.

24. Kosińska J, Billing-Marczak K, Krotkiewski M. New unknown functions of vitamin D [in Polish]. Med Rodz. 2008:2:34-47.

25. Glerup H, Mikkelsen K, Poulsen L, et al. Hypovitaminosis D myopathy without biochemical signs of osteomalacic bone involvement. Calcif Tissue Int. 2000;66:419-424. 
26. Arai $\mathrm{H}$, Miyamoto $\mathrm{Kl}$, Taketani $\mathrm{Y}$. A vitamin $\mathrm{D}$ receptor gene polymorphism in the translation initiation codon: Effect on protein activity and relation to bone mineral density in Japanese women. J Bone Miner Res. 1997;12:915-921.

27. Geusens P, Vandevyver C, Vanhoof J, Cassiman JJ, Boonen S, Raus J. Quadriceps and grip strength are related to vitamin D receptor genotype in elderly non-obese women. J Bone Miner Res. 1997;12:2082-2088.

28. Mahjoubi S, Kandara H, Mekni S, et al. Vitamin D status in acromegaly: A comparative study. Endocrine Abstracts. 2018;56:P844.

29. Halupczok-Żyła J, Jawiarczyk-Przybyłowska A, Bolanowski M. Patients with active acromegaly are at high risk of $25(\mathrm{OH}) \mathrm{D}$ deficiency. Front Endocrinol (Lausanne). 2015;6:89.

30. Ilhan M, Toptas-Hekimoglu B, Yaylim I, et al. Investigation of the vitamin D receptor polymorphisms in acromegaly patients. Biomed Res Internat. 2015;2015:625981.

31. Dawson-Hughes B, Heaney RP, Holick MF, Lips P, Meunier PJ, Vieth R. Estimates of optimal vitamin D status. Osteoporos Int. 2005;16:713-716.

32. McMahon L, Schwartz K, Yilmaz O, Brown E, Ryan LK, Diamond G. Vitamin D-mediated induction of innate immunity in gingival epithelial cells. Infect Immun. 2011;79:2250-2256.

33. Miley DD, Garcia MN, Hildebolt CF, et al. Cross-sectional study of vitamin $D$ and calcium supplementation effects on chronic periodontitis. J Periodontol. 2009;80:1433-1439.

34. Hildebolt CF. Effect of vitamin D and calcium on periodontitis. J Periodontol. 2005;76:1576-1587.

35. Garcia MN, Hildebolt CF, Miley DD, et al. One-year effects of vitamin $D$ and calcium supplementation on chronic periodontitis. J Periodontol. 2011;82:25-32.

36. Dietrich T, Joshipura KJ, Dawson-Hughes B, Bischoff-Ferrari HA. Association between serum concentrations of 25-hydroxyvitamin $\mathrm{D}_{3}$ and periodontal disease in the US population. Am J Clin Nutr. 2004;80:108-113.

37. Stein SH, Livada R, Tipton DA. Re-evaluating the role of vitamin D in the periodontium. J Periodont Res. 2013;49:545-553.

38. Perayil J, Menon KS, Kurup S, et al. Influence of vitamin D \& calcium supplementation in the management of periodontitis. J Clin Diagn Res. 2015;9:35-38.

39. Hiremath VP, Rao CB, Naik V, Prasad KV. Anti-inflammatory effect of vitamin $D$ on gingivitis: $A$ dose-response randomised control trial. Oral Health Prev Dent. 2013;11:61-69.

40. Krall EA, Wehler C, Garcia RI, Harris SS, Dawson-Hughes B. Calcium and vitamin $D$ supplements reduce tooth loss in the elderly. Am J Med. 2001;111:452-456.

41. Mangano F, Mortellaro C, Mangano N, Mangano C. Is low serum vitamin $D$ associated with early dental implant failure? A retrospective evaluation on 1625 implants placed in 822 patients. Mediat Inflamm. 2016;2016:5319718. 